\title{
Ex Vivo Analysis of the Debris Remaining in Flattened Root Canals of Vital and Nonvital Teeth After Biomechanical Preparation with Ni-Ti Rotary Instruments
}

\author{
Edi Wagner SASAKI \\ Marcos Aurélio VERSIANI \\ Danyel Elias da Cruz PEREZ \\ Manoel D. SOUSA-NETO \\ Yara T. Correa SILVA-SOUSA \\ Ricardo Gariba SILVA
}

Department of Dentistry, School of Dentistry of Ribeirão Preto, University of Ribeirão Preto, Ribeirão Preto, SP, Brazil

\begin{abstract}
The purpose of this study was to assess the presence of apical debris remaining in the apical third of flattened root canals of vital and nonvital teeth after biomechanical preparation with Ni-Ti rotary instruments. Fresh-extracted human mandibular incisors were used in this study. The teeth had clinical indication for extraction and were submitted to cold pulp vitality testing and radiographic examination. Eighteen teeth were selected and randomly assigned to two groups $(n=9)$, according to the clinical diagnosis, i.e., pulp vitality or pulp necrosis. The canals were instrumented with the ProTaper NiTi rotary system in the following sequence: S1 - up to the middle third; SX - at the cervical third; S2- up to the apical third; and S1, F1, F2, F3 - at the working length. The canals were irrigated with $1 \%$ sodium hypochlorite, dried and were submitted to the histological processing. Sections from the apical third were analyzed by an optical microscope (X40) that was coupled to a computer where the images were captured and analyzed using specific softwares. A grid was placed over these images to assess the total canal area and the areas with debris. Mann-Whitney U-test showed no statistically significant difference $(\mathrm{p}>0.05)$ between the teeth with pulp vitality $(6.49 \pm 3.39)$ and those with pulp necrosis $(5.95 \pm 2.22)$. It may be concluded that the clinical condition of pulp tissue did not interfere with the amount of debris remaining in the apical third of flattened root canals prepared with Ni-Ti rotary instruments.
\end{abstract}

Key Words: rotary instrumentation, root canal, pulp, debris, cleanness.

\section{INTRODUCTION}

During preparation of root canals, the mechanical action of instruments and chemical action of irrigants occur simultaneously, promoting cleaning and disinfection of the root canal system (1-3). While the instruments shape and widen the root canals, the irrigating solutions act dissolving the organic tissue (vital or necrotic) and removing debris and microorganisms $(2,4-6)$.

The pool of dentin chips, pulp remnants and other particles that remain loosely stuck within the intracanal space after biomechanical preparation in areas that were not accurately cleaned by action of chemical solutions and endodontic files is generally called debris $(6,7)$. The amorphous structure composed of dentin debris, organic material and microorganisms that is produced by mechanical instrumentation and adhere to the root canal walls obstructing the dentinal tubule openings constitutes the smear layer (6-8).

It is well known that the internal content of teeth with vital and necrotic pulp is different $(9,10)$. These denominations reflect clinical conditions of distinct pathologies with their respective histological character-

Correspondence: Prof. Dr. Manoel Damião Sousa-Neto, Rua Célia de Oliveira Meireles, 350, Jd. Canadá, 14024-070 Ribeirão Preto, SP, Brasil. Tel: +55-16-3623-6002. Fax: +55-16-603-6783. e-mail: sousanet@unaerp.br 
istics, which can difficult to canal cleaning. Therefore, it may be speculated that biomechanical preparation of root canals may produce debris and smear layer with different characteristics, indicating the need for different levels of cleaning (9-11). This process is also influenced by the internal tooth anatomy, techniques and irrigating solutions used during canal preparation (2,10-12).

Although root canal cleaning has been widely investigated, studies have shown controversial and even contradictory results, especially regarding the teeth used as test specimens. Suffridge et al. (13), for example, did not report the origin of the specimens. Extracted and stored teeth have been used in several studies (1,2,14,15). Usman et al. (16) utilized teeth from human cadavers, while other authors $(1,8)$ used freshextracted teeth. However, the pulpal conditions during the experiments have not been reported.

Considering that the critical analysis of an experiment methodology can influence its results, root canal cleaning should be evaluated taking into account the different conditions of pulp tissue during extraction. Therefore, the purpose of this ex vivo study was to assess the debris remaining in the apical third of flattened root canals of vital and nonvital teeth after biomechanical preparation with ProTaper rotary system.

\section{MATERIAL AND METHODS}

Fresh-extracted human mandibular incisors were used in this study. The teeth had clinical indication for extraction and pulp vitality was tested by application of an ice stick to the cervical third of the buccal surface of the teeth during $2 \mathrm{~s}$. Pulp was considered as vital when showed a positive painful response to cold stimulus while clinical necrosis was determined when no reaction was observed. Periapical radiographs were taken to investigate the presence of periapical lesions.

The extracted teeth were stored in $0.1 \%$ thymol solution at $9^{\circ} \mathrm{C}$ until use. Thereafter, they were washed in running water for $24 \mathrm{~h}$ to eliminate possible residues of thymol and were radiographed in a proximal and anterior-posterior direction. Eighteen teeth with single root canals, completely formed roots and without accentuated curvatures were selected and randomly assigned to two groups $(n=9)$ according to the clinical diagnosis, i.e., pulp vitality or pulp necrosis.

Conventional crown access was made and a size
15 K-type file (Dentsply Maillefer, Ballaigues, Switzerland) was passively introduced into each canal until its tip was seen at the apical foramen. The working length was established by subtracting $1 \mathrm{~mm}$ from this measurement. The canal cervical third was prepared with sizes 2 and 3 Gates-Glidden burs (Dentsply Maillefer) at low speed.

The canals were prepared using the ProTaper NiTi rotary system combined with an Endo-Kill TC engine and a NML-F16R handpiece (32330, NSK, Tokyo, Japan), regulating the torque and speed of each file. The instruments were used with a constant speed of $300 \mathrm{rpm}$ in the following sequence: S1 - up to the middle third with torque $\geq 1.0 \mathrm{~N}$.cm; SX - cervical third with torque $\geq 1.0 \mathrm{~N} . \mathrm{cm} ; \mathrm{S} 2$ - up to the apical third with torque of 1.0 N.cm; S1 - up to the working length with torque of 1.5 N.cm; F1 - up to the working length with torque of 2.0 N.cm; F2 - up to the working length with torque of $3.0 \mathrm{~N} . \mathrm{cm}$; and F3 - at the working length with torque of $3.0 \mathrm{~N}$.cm. Apical diameter was determined with the F3 instrument. For each experimental group, two sets of instruments were used. The canals were irrigated with $3 \mathrm{~mL}$ of $1 \%$ sodium hypochlorite at each change of file using sterile rubber syringe and Navytip needles (Ultradent, South Jordan, UT, USA). Aspiration was performed with Cappilary tips (Ultradent).

The apical third of each tooth was sectioned and removed. The specimens were placed in labeled plastic recipients containing $10 \%$ buffered formalin for $12 \mathrm{~h}$ for fixation of the organic tissue remnants. Afterwards, the specimens were washed in running water for $1 \mathrm{~h}$, decalcified in $10 \%$ glycoacetic acid and embedded in paraffin. Transversal serial 6 - $\mu \mathrm{m}$-thick cross-sections were obtained and stained with hematoxylin and eosin.

Ten sections of each root were selected for histomorphometric analysis in the following manner. The first section of the most apical portion of the working length was chosen. Then, 30 sequential sections were discarded and the 31st slice was selected. Again, 30 sequential sections were discarded and the 31st slice was chosen. This procedure was successively repeated until 10 sections of each root were selected. The cross-sections were examined with an optical microscope (Eclipse E 600; Nikon, Shinagawaku, Tokio, Japan) at X40 magnification. The image was captured using Adobe Premiere 5.1 software (Adobe Systems Inc., San Jose, CA) and were analyzed using Corel Photo Paint 10 software (Corel Corporation Inc., 
MN USA). A grid was placed over these images to assess the total canal area and the area with debris. The percentage of apical debris in the root canal was calculated. Data were analyzed statistically by MannWhitney U nonparametric test at 5\% significance level.

\section{RESULTS}

Debris were identified in $6.49 \pm 3.39 \%$ of the canal area of teeth with pulp vitality and in $5.95 \pm 2.22 \%$ of the canal area of teeth with necrotic pulp. No statistically significant difference ( $p>0.05$ ) was observed between the groups.

\section{DISCUSSION}

Root canal preparation is one of the most important steps in endodontic treatment. Its main purpose is to clean the root canal and its ramifications as thoroughly as possible, creating a healthy environment $(1,5,7)$. Several techniques and instruments have been developed for better cleaning and shaping of the root canal system, especially in cases with anatomic variations (5-7,10-12,14,15). However, deficiencies in biomechanical preparation are still observed, leading to an incomplete removal of organic and inorganic debris of the intracanal space $(9,14,15,17)$.

The outcomes of this study disclosed that the biomechanical preparation with ProTaper rotary instrumentation system did not promote a complete elimination of debris remaining within flattened canals, regardless of the pulpal condition (vital or necrotic) and even after the irrigation with $1 \%$ sodium hypochlorite. Sodium hypochlorite is frequently used as a canal lubricant and disinfectant and has the ability of dissolving pulp tissue remnants (4). It also acts in areas where the files cannot not reach $(17,18)$.

The results of this study suggested that root canal anatomy is actually more important that the pulp clinical condition for cleanliness. The difficulties in cleaning narrow, curved and flattened root canals had already been reported (5,7,10-12,19). Likewise, the results of this study revealed the presence of debris inside mechanically instrumented root canals, mainly in the isthmus region.

Another factor to be considered is that the biomechanical preparation with Ni-Ti rotary instruments is an alternative technique that brought a series of conceptual changes in comparison to manual instrumentation, increasing the efficiency and decreasing the time for endodontic preparation $(3,6,12,13,15)$. Specimen examination under optical microscopy revealed debris in the areas of the canals that were not reached by the rotary instruments, regardless of the pulp condition. These results are consistent with those of previous investigations $(1,14)$, which reported that rotary instrumentation of flattened root canals did not allow the contact of instrument with all canal walls.

In view of this, further clinical protocols should be developed to allow that all root canal areas can be reached during biomechanical preparation. Engine-driven instrumentation offers an oscillatory movement and can provide better removal of debris. The findings of this study widen the perspectives for future research that investigate the efficacy of rotary instruments for root canal cleaning in teeth with different pulp conditions.

\section{RESUMO}

O objetivo deste estudo foi avaliar a presença de debris no terço apical de canais radiculares achatados de dentes com polpa vital ou não-vital após preparo biomecânico com instrumentos rotatórios de níquel-titânio. Incisivos humanos inferiores recentemente extraídos for usados neste estudo. Os dentes tinham indicação para exodontia e o diagnóstico clínico do estado pulpar foi realizado mediante teste de vitalidade com frio e exame radiográfico. Dezoito incisivos inferiores humanos foram selecionados e distribuídos em dois grupos ( $\mathrm{n}=9$ ), de acordo com o diagnóstico clínico: dentes com a polpa viva ou dentes com a polpa necrosada. Os canais radiculares foram instrumentados com o sistema rotatório ProTaper com instrumentos de NiTi na seguinte seqüência: S1- até o terço médio; SX - no terço cervical; S2 - até no terço apical; e S1, F1, F2, F3 - no comprimento de trabalho. Os canais foram irrigados com hipoclorito de sódio a $1 \%$, secos e submetidos ao processamento histológico. Cortes do terço apical foram analisados em microscópio ótico (40X) acoplado a um computador onde as imagens resultantes foram capturadas e analisadas utilizando programas específicos. Uma grade foi colocada sobre estas imagens para avaliar a área total do canal e as áreas com debris. O teste de Mann-Whitney mostrou não haver diferença estatisticamente significante $(p>0,05)$ entre os dentes com vitalidade pulpar $(6,49 \pm 3,39)$ e aqueles com necrose pulpar $(5,95 \pm 2,22)$. Concluiu-se que o estado clínico pulpar não interferiu na quantidade de debris remanescentes no terço apical de canais radiculares achatados preparados com instrumentos rotatórios de $\mathrm{NiTi}$.

\section{REFERENCES}

1. Barbizam JVB, Fariniuk LF, Marchesan MA, Pécora JD, Sousa-Neto MD. Effectiveness of manual and rotary instrumentation techniques for cleaning flattened root canals. J 
Endod 2002;28:365-366.

2. Baratto-Filho F, Carvalho Jr. JR, Fariniuk LF, Sousa-Neto MD, Pécora JD, Cruz-Filho AM. Morphometric analysis of the effectiveness of different concentrations of sodium hypochlorite associated with rotary instrumentation for root canal cleaning. Braz Dent J 2004;15:36-40.

3. Albrecht LJ, Baumgartner JC, Marshall JG. Evaluation of apical debris removal using various sizes and tapers of Profile GT files. J Endod 2004;30:425-428.

4. Spanó JCE, Barbin EL, Santos TC, Guimarães LF, Pécora JD. Solvent action of sodium hypochlorite on bovine pulp and physicochemical properties of resulting liquid. Braz Dent $\mathrm{J}$ 2002;12:154-179.

5. Weiger R, Elayouti A, Löst C. Efficiency of hand and rotary instruments in shaping oval root canals. J Endod 2002;28:580583.

6. Hülsmann M, Gressmann G, Schäfers F. A comparative study of root canal preparation using Flexmaster and Hero 642 rotary Ni-Ti instruments. Int Endod J 2003;36:358-366.

7. Rödig T, Hülsmann M, Mühge M, Schäfers F. Quality of preparation of oval distal root canals in mandibular molars using nickel-titanium instruments. Int Endod J 2002;35:919928.

8. Siqueira Jr JF, Araújo MCP, Garcia PF, Fraga RC, Dantas CJS. Histological evaluation of the effectiveness of five instrumentation techniques for cleaning the apical third of root canals. J Endod 1997;23:499-502.

9. Gutarts R, Nusstein J, Reader A, Beck M. In vivo debridement efficacy of ultrasonic irrigation following hand-rotary instrumentation in human mandibular molars. J Endod 2005;31:166-170.

10. Jung IY, Seo MA, Foaud AF, Spangberg LSW, Lee SJ, Kim HJ, Kum KY. Apical anatomy in mesial and mesiobuccal roots of permanent first molars. J Endod 2005;31:5:364-368.
11. Mannocci F, Peru M, Sherriff M, Cook R, Pitt Ford TR. The isthmuses of the mesial root of mandibular molars: a microcomputed tomography study. Int Endod J 2005;38:558-563.

12. Schäfer E, Schlingemann R. Efficiency of rotary nickeltitanium k3 instruments compared with stainless steel hand K-Flexofile. Part 2. Cleaning effectiveness and shaping ability in severely curved root canals of extracted teeth. Int Endod J 2003;36:208-217.

13. Suffridge CB, Hartwell GR, Walker TL. Cleaning efficiency of nickel-titanium GT and .04 rotary files when used in a torquecontrolled rotary handpiece. J Endod 2003;29:346-348.

14. Fariniuk LF, Baratto-Filho F, Cruz-Filho AM, Sousa-Neto MD. Histologic analysis of the cleaning capacity of mechanical endodontic instruments activated by the ENDOflash system. J Endod 2003;29:651-653.

15. Ferreira RB, Alfredo E, Porto De Arruda M, Silva-Sousa YT, Sousa-Neto MD. Histological analysis of the cleaning capacity of nickel-titanium rotary instrumentation with ultrasonic irrigation in root canal. Aust Endod J 2004;30:56-58.

16. Usman N, Baumgartner JC, Marshall JG. Influence of instrument size on root canal debridement. J Endod 2004;30:110-112.

17. Colak M, Evcil S, Bayindir Y, Yigit N. The effectiveness of three instrumentation techniques on the elimination of Enterococcus faecalis from a root canal: an in vitro study. J Contemp Dent Pract 2005;6:94-106.

18. Siqueira Jr JF, Rjcas IN, Santos SR, Lima KC, Magalhães FA, Uzeda M. Efficacy of instrumentation technique and irrigation regimens in reducing the bacterial population within root canals. J Endod 2002;28:181-184.

19. Wu MK, Van Der Sluis LWM, Wesselink PR. The capability of two hand instrumentation techniques to remove the inner layer of dentine in oval canals. Int Endod J 2003,36:218-224.

Accepted June 20, 2006 